\title{
CHANGES RELATED TO THE FIRST AID IN WATER LIFESAVING IN POLAND (1962-2020)
}

\author{
Iwona Tabaczek-Bejster ${ }^{A, B, D}$ \\ Institute of Health Sciences, Medical College of Rzeszow University, Poland \\ ORCID: 0000-0002-1233-6324 \\ Jerzy Kiszka ${ }^{A, B}$ \\ Institute of Health Sciences, Medical College of Rzeszow University, Poland \\ ORCID: 0000-0002-7361-1019
}

\section{Grzegorz Konieczny^, B, D}

Faculty of Health Sciences and Physical Education, Witelona State University of Applied Sciences in Legnica, Poland ORCID: 0000-0002-6839-1082 | e-mail: gkonieczny@wp.pl

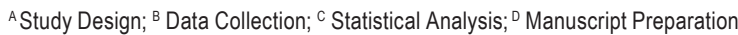

\begin{abstract}
Ahstract In 1962, Water Volunteer Rescue Service (WOPR) was established. From the beginning of its activity, this organization has established cooperation with the Polish Society of Anaesthesiology. In 1997, the regulation of the Council of Ministers was published in the Journal of Laws of the Republic of Poland, defining the safety conditions for people who are swimming, bathing and practicing water sports. WOPR was authorized to perform tasks related to the safety of persons staying at the body of water. In 2007, a breakthrough in the development of the first aid in water rescue took place in Poland. On January 1, 2007, the Law on State Emergency Medical Services entered into force. On its basis, the system of State Emergency Medical Services was created. WOPR has become one of the units cooperating with this system. On January 1, 2012, the new act on the safety of people staying in water areas was introduced. On its basis, radical changes in lifesaving have been made.

The study analyzed the evolution of the first aid rules for lifesavers in Poland. It presents changes in ways of conduct in artificial lung ventilation and chest compressions in drowning people.
\end{abstract}

Key worlds water lifesaving, first aid, resuscitation, WOPR, history

\section{Introduction}

People in course of their life often died in water during an accident or suicide. Drowning is one of the more common causes of death in young people and is one of the leading causes of death in this age group (Peden, McGee, 2004). The role of lifesavers is to save drowning people and prevent them from dying. Methods of conducting resuscitation procedures and methods of rescuing drowning people have changed over the years following updated knowledge and technical novelties. 
In ancient times, the ability to swim was not very popular. Ways of rescuing the drowning were significantly different from those present and were less effective. It was unclear how to restore vital functions in a person with cardiac arrest. Mechanisms associated with drowning were not known, although attempts were made to find ways to help a person who suddenly lost their vital functions.

The oldest example of artificial mouth-to-mouth breathing is found in the Old Testament, in the Second Royal Book. The prophet Elisha brought a boy back to life by putting his mouth to the child's mouth. Hippocrates, who lived between 460-377, was performing further attempts to save lives using tracheotomy. In 1667, R. Hook used lungs inflation with bellows, which allowed to maintain the life of experimental animals (Skalski, 2003a).

The development of modern methods of reviving people rescued from water in the world dates back to the eighteenth century.

Commercial trade by sea and a large number of people working in the Dutch and British ports have contributed to a significant increase in the number of drowning. This situation led in the 1770s to the creation of companies dealing with rescuing drowning people, they attempted to provide adequate artificial ventilation during the first aid. In 1767, the first organization of this type was founded in Amsterdam - the Society for the Recovery of Drowned Persons (Cooper, Cooper, Cooper, 2006).

A detailed description of lung ventilation and intubation was done in 1776 by W. Cullen and Lord Cathacart. In case of ineffective mouth-to-mouth or mouth-to-nose ventilation they recommended administering air with a syringe into the endotracheal tube (Skalski, 2003b).

In the Polish territories, the beginning of resuscitation is considered 1805, when J. Śniadecki published in Vilnius a work entitled O przypadkach pozornej śmierci i sposobach przywracania tak obumarłych osób do życia [On cases of apparent death and ways of restoring such dead people to life]. It was a compendium of conduct in life emergency situations based on the experience of doctors from Europe and his own. The author described the mouth-to-mouth method in the following way: "... At the end, put own lips to the lips of a dead fetus, inflate his chest slowly, and then, by slowly compressing the blown air, squeeze in again and repeat it until the baby breathes on his own..." (Śniadecki, 1840, pp. 233-290). In the event of failure, a tracheotomy was to be performed. In his work, J. Śniadecki also wrote about double bellows, by means of which air was forced into the lungs and pulled out. He also organized and equipped a rescue point for drowning people (Śniadecki, 1840).

A few years after the introduction of endotracheal tubes and "bellows", they were banned by the Royal Life Saving Society in London due to the high mortality after their use (Skalski, 2003b).

In the nineteenth century, the search for new methods useful in resuscitation began. In France, air insufflation was replaced by D'Etoile's passive movements. In 1882, the first attempts to apply direct heart massage by M. Schiff were carried out (Cooper et al.). In 1891, Dr. F. Mass performed the first effective chest compressions in a man, restoring life to a patient who had stopped the circulation during anesthesia with chloroform (Taw, 1991).

In the twentieth century there was a breakthrough associated with the creation of a framework for resuscitation.

In 1898, the Imperial Society for Sinking Rescue in Kalisz started its activity in Poland, and this year was adopted as the beginning of organized water rescue in Polish territories. In 1902, for the needs of the Society, Dr. L. Wernic published a book entitled: How to save drowning? It was the first book in Polish containing a description of methods and ways for rescuing drowning people (Marszal-Hall's, Sylvester's and Lamborde's method) (Wernic, 1994). 
In 1947, the American cardiac surgeon C. Beck performed the first successful defibrillation. He used it with a 14-year-old boy who suffered cardiac arrest during cardiac surgery (Beck, Pritchard, Feil, 1947).

In 1954, J. Elam was the first to prove that the air exhaled by the rescuer is sufficient to maintain adequate oxygenation of the victim.

Thanks to these tests, mouth-to-mouth ventilation has been rediscovered and introduced into clinical practice. The descriptions of techniques for external heart massage were gradually improving. In 1958, it was described by W. Kouwenhoven (Cooper et al., 2006).

Dr P. Safar (Baskett, 2001) is considered to be the founder of the principles of saving lives, known all over the world today. Thanks to $A B C$ of resuscitation: $A$ - restoring airways patency, $B$ - breathing, $C$ - external heart massage, it was possible to effectively save life.

P. Safar in his studies on the patency of the upper respiratory tract noticed that in unconscious patients who have an extended neck and supported mandible, the airways open (Safar, Escarraga, Chang, 1954).

P. Safar was nicknamed the "father of resuscitation". He was the first to introduce research on the effects of resuscitation. In 1957 he published the first reference book on resuscitation entitled $A B C$ of resuscitation. At the beginning of the 1960s, these guidelines, known currently worldwide as cardiopulmonary resuscitation (CPR), were introduced into clinical practice (14). P. Safar was also the first to apply hypothermia, which was among the later guidelines of resuscitation in 2005 (created by the European Resuscitation Council in the form of the so-called moderate hypothermia) (Safar, Kochanek, 2002).

In 1960, P. Safar presented the results of his work at the symposium of the Scandinavian Society of Anaesthesiologists in Norway. He made friends there with Asmund Laerdal, a producer of toys from Norway. This cooperation resulted in the creation of a mannequin for learning resuscitation called "Resusci Anne". The mannequin's face was inspired by the face of an unknown girl who had drowned in the Seine (Acierno, Worrell, Safar, 2007).

Since then, cardiopulmonary resuscitation has been disseminated not only among professional rescuers.

The first guidelines for cardiopulmonary resuscitation were published in 1966. Since then, these guidelines have been repeatedly updated by two world organizations dealing with resuscitation standards, the American Heart Association (AHA) and the European Resuscitation Council (ERC). All of these recommendations were aimed at restoring not only breathing and heart action, that is resuscitation, but also bringing back the patient's awareness, i.e. reanimation (Kucmin, Płowaś-Goral, Nogalski, 2015).

\section{Changes in the regulations on the first aid in water lifesaving in Poland}

In the 1960s when modern methods of resuscitation were created worldwide, an organization dealing with the rescue of drowning was being established in Poland. Earlier, since 1926, the Commission for Water Lifesaving at the Polish Swimming Association (PZP) dealt with matters related to water lifesaving. In 1945, the PZP was revived, and in 1947 a Water Lifesaving Department (Sprawozdanie, 1947) was also established. Its activity bear fruit only after 1952, when on the initiative of D. Bogajewski, an employee of the Academy of Physical Education in Warsaw (AWF) and a PZP activist, water lifesaving entered the curriculum of this university. In the following years, issues related to water lifesaving were included in the curricula of all universities of this type. Since 1958, there has been a dynamic development of water lifesaving in Poland (Witkowski, 1975, pp. 56-60). 
On April 11, 1962, by ordinance No. 74 of the chairman of the Main Committee of Physical Culture and Tourism, the Water Volunteer Rescue Service (WOPR) was established. This organization associates volunteers, lifesavers trained in water rescue and first aid.

One of the precursors of water lifesaving in Poland was M. Witkowski (Tabaczek-Bejster, 2012) a graduate of the University of Physical Education in Warsaw and a didactic and academic employee of this university. He was also the author of the book Saving the drowning, published in 1958. This manual describes the causes and stages of sinking, there were tips (how to give first aid to the drowning and methods of swimming and pulling the drowning out of water) used in training lifesavers. It also contains legal issues useful in the work of a water lifesaver (Witkowski, 1975, Tabaczek-Bejster, Konieczny, 2020).

In the chapter of the book entitled Providing help after recovery from the water, photographs and description of restoring airways patency, ventilation and external cardiac massage are provided. The treatment of an unconscious person, pulled out of the water, has also been discussed. First of all, an ambulance was to be called and then life support was to be performed, such as:

- preparatory activities,

- artificial ventilation,

- indirect heart massage.

In the 1960s, artificial breathing apparatus was introduced for lifesavers work in Poland. It was Polish "AB-9", "AM-4" type device modeled on German "Medi" type devices. Later, they were replaced by Polish "Ambu" type G-12. During the use of the apparatus, the rescue position and the frequency of respirations were the same as for the direct method. A mouthpiece was inserted when the Medi, AB-9, and AM-4 were used. The mask had to adhere well. A spongy pad attached to the mask with a tape was placed under the head in the occipital part, and a clamp was placed on the nose. The rescuer put into the mouth the other end of the cord ended with a mouthpiece and a nose clip. The mouth-to-mouth method was also used on the boat. A rescued person was in a half-sitting position with his head tilted back.

In 1969, PZP finally handed over all matters and documentation related to water rescue services to WOPR Main Board. The central authorities of WOPR introduced new training programs, regulations, instructions and levels of lifesavers. The following degrees were valid: junior lifesaver, lifesaver, senior lifeguard, lifeguard instructor and instructor and lecturer in water rescue (V National Congress, 1987).

Since the beginning of its activity, WOPR has established cooperation with the Society of Polish Anesthesiologists (TAP) in order to exchange experiences during resuscitation. In 1972, there was a scientific symposium TAP and WOPR, dedicated to providing assistance on land and in water (Przylipiak, Witkowski, 1977, pp. 171-186).

In 1975, the WOPR Training Commission issued training instructions no. 1/75, which increased the training requirements for particular water rescue degrees (Training instruction, 1975).

In 1977 a book was published by M. Przylipiak and M. Witkowski titled: Diving in independent air apparatus and saving drowning. It provides useful information for people participating in the courses for each step of the water rescuer.

In the second half of the 1970s, the frequency of artificial respiration was modified. It was 10-12 times per minute. When ventilating in small children it was necessary to cover the mouth and nose with the same position of the head and torso as in adults. The air was blown 18-22 times per minute. If there was a cardiac arrest, 
cardiopulmonary resuscitation (CPR) was initiated in addition to cardiac arrest. The rescuer kneeled down on the side of the victim and in the manner described above he made artificial breathing first - initially 3 inhalations, and then 15 chest compressions. Next 2 inhalations and 10-12 compressions alternately. When the help was provided by two rescuers, one of them performed first two breaths, and the other 10-12 compressions. Subsequently, after each inhalation into the victim's mouth, 5-6 compressions were applied to the chest (Przylipiak, Witkowski, 1977, pp. 171-186).

Central training of senior rescuers has started since 1985 in the WOPR training center in Tama on the Rajgrodzkie Lake. Due to the fact that lifesavers from all over Poland came there, the subject of training was also unified in the field of first aid (Żagle, 1985).

Subsequent years did not bring significant modifications in the way of cardiopulmonary resuscitation. In 1992, the International Liaison Committee on Resuscitation (ILCOR) was established. It brought together the world organizations involved in creating standards in resuscitation. The founders of the committee were, among others American Heart Association (AHA), European Resuscitation Council (ERC), Australian and New Zealand Committee on Resuscitation (ANZCOR), Resuscitation Councons of Southern Africa (RCSA). ILCOR unified conduct in resuscitation on all continents publishing in 1997 their standards of conduct (Malinowska-Zaprzałka, 1998) in medical journals ("Resuscitation", "Circulation", "British Journal of Anaesthesia").

On June 7, 1997, a regulation of the Council of Ministers was published in the Journal of Laws of the Republic of Poland, which defines the safety conditions for people who are swimming, bathing and practicing water sports. It was the same year in which the ILCOR guidelines for resuscitation were created. The ordinance stipulates that the WOPR is authorized to perform tasks related to the safety of persons staying above the water. It also specifies types of bathing areas and their equipment, the number of lifesavers on a given water area and first aid medical equipment in which a swimming pool and bathing areas should be equipped.

According to Annex 4 of the regulation regarding the ordinance, each lifeboat and each rescue station should contain first aid medical equipment. Annex 6 contained a detailed list of medical equipment, medicines and sanitary articles in which swimming pools and bathing areas should be equipped. Medical equipment was:

- a device for artificial respiration 1 piece,

- portable oxygen inhaler 1 piece,

- straight and curved scissors 2 pieces,

- tourniquet (wide rubber band) 1 piece,

- immobilizing splint 3 pieces,

- a medicine glass 1 piece,

- thermometer 1 piece,

- masks for artificial respiration,

- rubber gloves (Regulation, 1997).

In 1998, the European Resuscitation Council issued guidelines based on recommendations for Cardiopulmonary resuscitation and emergency procedures in cardiac disorders. They were updated every 5 years on the basis of reliable and current studies. The last update took place in 2015 (Table 1). 
Table 1. Changes in basic resuscitation procedures in an adult taken out of water in years 1997-2020

\begin{tabular}{|c|c|c|c|c|}
\hline ACTION & Guidelines ILCOR 1997 & $\begin{array}{l}\text { Guidelines } \\
\text { ERC } 2000\end{array}$ & $\begin{array}{l}\text { Guidelines } \\
\text { ERC } 2005\end{array}$ & $\begin{array}{l}\text { Guidelines } \\
\text { ERC } 2015\end{array}$ \\
\hline Restoring Airways Patency & \multicolumn{4}{|c|}{$\begin{array}{l}\text { Tilting the head back and lifting the mandible } \\
\text { or balancing it in the event of spinal injury }\end{array}$} \\
\hline The foreign body in the airways & $\begin{array}{l}\text { Perform the Heimlich } \\
\text { maneuver }\end{array}$ & $\begin{array}{l}\text { Perform chest } \\
\text { compressions }\end{array}$ & $\begin{array}{l}\text { Perform epigastrium's } \\
\text { compression }\end{array}$ & $\begin{array}{l}\text { Do not check routinely, } \\
\text { delete if visible }\end{array}$ \\
\hline Artificial ventilation method & $\begin{array}{l}\text { Mouth to mouth or mouth } \\
\text { to nose }\end{array}$ & Mouth to mouth & $\begin{array}{l}\text { Mouth to mouth or mouth } \\
\text { to nose (in water) }\end{array}$ & Mouth to mouth \\
\hline $\begin{array}{l}\text { The number of initial rescue } \\
\text { breaths }\end{array}$ & $\begin{array}{l}2 \text { breaths lifting up the chest } \\
\qquad \text { (max } 5 \text { attempts) }\end{array}$ & $\begin{array}{c}2 \text { breaths } \\
\text { (max } 5 \text { attempts, previously } \\
\text { the rescuer takes a deep } \\
\text { breath) }\end{array}$ & \multicolumn{2}{|c|}{5 breaths } \\
\hline Respiratory volume & $400-500 \mathrm{ml}$ & $700-1000 \mathrm{ml}$ & \multicolumn{2}{|c|}{$500-600 \mathrm{ml}$} \\
\hline Pulse test & Carotid artery & $\begin{array}{c}\text { NO, } \\
\text { instead, look for signs } \\
\text { of blood circulation }\end{array}$ & \multicolumn{2}{|c|}{ NO } \\
\hline Place of chest compressions & \multicolumn{2}{|c|}{ Lower half of the sternum } & \multicolumn{2}{|c|}{ The center of the chest } \\
\hline Depth of compressions & $1 / 3$ of the depth of the chest & $\begin{array}{c}1 / 3 \text { of the antero-posterior } \\
\text { dimension }\end{array}$ & $4-5 \mathrm{~cm}$ & $5-6 \mathrm{~cm}$ \\
\hline The frequency of compressions & & $100 / \mathrm{min}$ & & $100-120 / \min$ \\
\hline Number of rescue breaths & $\begin{array}{c}2 \text { effective breaths } \\
\text { (max } 5 \text { attempts) lasting } \\
1.5 \mathrm{sec} .\end{array}$ & 2 breaths lasting 2 seconds & $\begin{array}{c}2 \text { breaths (max } 2 \\
\text { ventilation attempts) }\end{array}$ & 2 breaths lasting $1 \mathrm{sec}$. \\
\hline $\begin{array}{l}\text { The ratio of compressions } \\
\text { to breath }\end{array}$ & $\begin{array}{l}15: 2 \text { when } 1 \text { lifeguard } \\
5: 1 \text { when } 2 \text { rescuers }\end{array}$ & $15: 2$ & & $: 2$ \\
\hline $\begin{array}{l}\text { Shifts of rescuers in compressing } \\
\text { the chest }\end{array}$ & When the res & uer is tired & $1-2$ minutes & Every 2 minutes \\
\hline $\begin{array}{l}\text { Evaluation of the return } \\
\text { of circulation }\end{array}$ & Every $\mathrm{m}$ & inute & $\begin{array}{l}\text { Only if he/she starts to } \\
\text { breathe properly }\end{array}$ & $\begin{array}{c}\text { The return } \\
\text { ofspontaneouscirculation } \\
\text { (coughs, moves) }\end{array}$ \\
\hline $\begin{array}{l}\text { Keeping CPR for } 1 \mathrm{~min} \text {. before } \\
\text { going for help }\end{array}$ & & YES & & \\
\hline Using the AED & & NO & & YES \\
\hline
\end{tabular}

Source: own elaboration of ILCOR and ERC guidelines in 1997-2020.

From January 1, 2000, new programs of courses for WOPR lifesavers and instructors as well as specialist trainings were introduced by the resolutions of the WOPR presidium. The previous training instructions have ceased to apply. Small changes in the naming of rescue degrees were introduced: WOPR junior lifesaver, WOPR lifesaver, WOPR senior lifeguard, WOPR instructor, WOPR instructor-lecturer (Resolution, 1999). First aid and resuscitation procedures were taught on courses along with issues related to water rescue. The training stages and programs were in force until December 31, 2009 (Decision, 2009).

The 2000 ERC guidelines resulted in several important changes in the first aid provided by medical personnel and non-medical rescuers included in organizations providing assistance (including WOPR). Heart rate testing was not recommended, as in some cases it was an activity requiring more time than 10 seconds. Instead, two rescue breaths had to be performed and seek signs of blood circulation. The guidelines recommended that chest 
compressions and rescue breaths should be carried out only by one witness of the event at a time. The ratio of chest compressions to rescue breaths was $15: 2$. Only medical personnel and rescuers of trained teams such as lifesavers could conduct CPR in two persons. It was also pointed out that there is no need to clean the airways from the water. Cervical spine injury was relatively rare. It was not recommended to stabilize it routinely (Watson, Cummings, Quan, Bratton, Weiss, 2001).

The European Resuscitation Council guidelines of 2005 introduced a new definition of drowning - a process that initially results in a respiratory disorder caused by flooding or immersion in a liquid. This meant that at least the first part of the airways is immersed in water. A person after the drowning episode should have been taken out of the water as soon as possible. The risk of damage to the cervical spine was low in the drowning, at around $0.5 \%$. In the case of a person with respiratory arrest, it was recommended to start ventilating in shallow water as soon as possible with the mouth-to-nose method. The rescue breaths should have been carried out for one minute. If the respiration did not come back after this time, the further course of action depended on the distance from the shore (time to reach up to $5 \mathrm{~min}$. - continue rescue breaths in water, time to reach above $5 \mathrm{~min}$ - perform breaths for 1 minute and swim to shore as soon as possible).

After the victim is pulled ashore, chest compressions should begin (Soar et al., 2005).

The breakthrough in the development of first aid in water rescue in Poland took place in 2007, when on 1 January the Act on State Emergency Medical Services (PRM) entered into force. It created the system of State Emergency Medical Services which provides help to every person whose health and life are threatened. WOPR has become one of the units cooperating with the PRM system. Pursuant to the act, water rescuers were obliged to raise their qualifications by completing a qualified first aid course (KPP). The Minister of Health issued a regulation on the organization and conduct of the course. The subject of the 66-hour training was extensive, including the treatment of unconscious and resuscitation of an adult, a child, a baby and a newborn. The training included providing assistance during shock, convulsions, diabetes, myocardial infarction, stroke, poisoning and flooding.

The principles of defibrillation of the injured by the semi-automatic and automatic method were taught. Great emphasis during the course was placed on the management of injuries and triage during mass accidents. After such a course the lifesaver was well prepared for performing qualified first aid. The re-exam (recertification) took place every 3 years.

A lifesaver time having the title of "rescuer" at the same, after completing the KPP course was working on a lido or a swimming pool equipped with a first aid kit R1 (bag or backpack). The medical kit contained:

a) equipment for cardiopulmonary resuscitation:

- a manual aspirator - 1 piece,

- a mask for artificial respiration - 1 piece,

- oropharyngeal tubes for children and adults - 1 set,

- face mask for children and adults - 1 piece each,

- a bag valve mask with oxygen reservoir - 1piece,

- nasal cannula, oxygen mask for an adult and a child -1 piece each,

- oxygen cylinder with reducer - 1 piece;

b) dressings;

c) spray for burns and disinfectants (Regulation, 2012). 
Following the changes in water rescue in Poland and wishing to adjust the structure of the degrees to the International Life Saving Federation (ILS), WOPR Central Board presidium adopted Resolution No. 5/6/09 of December 5, 2009 on the WOPR lifesavers' and instructors' degrees. From January 1, 2010, the volunteer division introduced the rank of the junior WOPR lifesaver and WOPR lifesaver, while in the professional division the water rescuer of the swimming pool, inland water lifeguard, sea water lifeguard, and the senior water lifeguard. In addition, three instructor degrees were established: WOPR junior instructor, WOPR instructor, WOPR instructorlecturer. They lasted until December 31, 2012.

The candidate joining the course for the degree of professional rescuer (swimming pool, inland, sea) must have a WOPR lifesaver degree and the title of "rescuer" after completing the KPP course. Training for professional degrees in their programs had introduced issues in the field of qualified first aid. Improvements were made in helping a person in shock, with injuries and back injuries. CPR was carried out with the use of the first aid kit R1 according to the previously created scenario. The actions using the mannequin - an adult, a child, a baby - were carried out individually or in a team of two rescuers (Decision, 2010).

The new Act on the safety of persons residing in water areas entered into force on January 1,2012 . On the basis of this, radical changes have been introduced in water rescue in Poland. A person who wanted to become a lifesaver had to meet 4 conditions:

a) have knowledge and skills in the field of rescue and swimming techniques (training of water rescuers);

b) other qualifications useful in water rescue (patent or other permission useful in water rescue);

c) complete the KPP course (obtaining the title of a rescuer);

d) perform service or be a member in an entity authorized to perform water rescue (Kołodziej, TabaczekBejster, Dudziak, 2014).

After 50 years, WOPR lost its monopoly on water rescue activities. Over the next years of the Act's existence, over 100 entities authorized to perform this type of activity were established. The largest of them is the Water Rescue of the Republic of Poland, Masurian Volunteer Rescue Service, Masurian Rescue Service. Unfortunately, some of them are only focused on commercial activities. These entities do not always have the required rescue equipment and instructors needed to conduct training. There was also no body authorized to control them. This may translate into a reduction in the level of training of water rescuers, which used to be very high (Tabaczek-Bejster, Kiszka, Ozga, 2018) in the previous years.

In 2015, the European Resuscitation Council (ERC) published the 2015 CPR Guidelines. They included for the first time the "chain of survival in drowning". It consists of five links that should be used during a sinking accident. They have a direct impact on the survival rate in drowning. These include: prevent drowning (be safe in and around water), recognize distress (ask someone to call for help), provide flotation (to prevent submersion), remove from water (only if safe to do so), provide care as needed (seek medical attention). For the first time, these guidelines introduce the use of AED in the sinking algorithm. This will undoubtedly contribute to the need for providing emergency services to the AED, by the administrators of various types of bathing areas in Poland (Truhlár, Deakin, Alfonzo, Bierens, Brattebo, 2015).

In December 2019, the Minister of Health changed the regulation on the course KPP. It states that a water lifeguard with a certificate of passing the qualified first aid exam, the validity of which expires no later than 3 months from the date on which a water lifeguard takes the exam, may proceed to recertification. In addition, a water lifeguard must be employed in units cooperating with the system, work in them or be a member of it (Regulation, 2019). 
At the beginning of 2020, the SARS CoV-2 coronavirus epidemic broke out in Poland and in the world. Therefore, the ILCOR has made recommendations for CPR in patients with confirmed or suspected COVID-19. They have been published by the ERC under the name of the COVID-19 Guidelines. They have increased the emphasis on the use of personal protective equipment. Basic resuscitation procedures in adults introduced the necessity to assess the breathing without opening the airway and not placing the rescuer's face next to the victim's mouth. Rescue breathing was abandoned in adults and it was recommended to wear a protective mask on a person whose chest was compressed. If an oxygen mask and an oxygen cylinder are available and there is no training in ventilation with a self-inflating bag, oxygen supply through the oxygen mask and the compression of the chest was recommended. After completion of CPR, it was recommended to wash hands with soap or disinfect them, and contact the health authorities for information on screening tests after contact with a person with suspected or confirmed COVID-19 (Olasveengen et al., 2020).

On March 20, 2020, the government introduced an epidemic throughout the country. The KPP courses and exams were suspended, and many rescuers were not authorized to provide qualified first aid. To enable rescuers to fulfill their tasks, the government extended the validity of certificates expiring during the epidemic period to 60 days from the date of cancellation of the epidemic (Act, 2020).

On April 10, 2021, the Virtual Symposium of the Polish Resuscitation Council is planned on the occasion of the 20th anniversary of activity, at which the new Resuscitation Guidelines 2021 will be presented.

\section{Conclusions}

Over the centuries, there has been a significant development of cardiopulmonary resuscitation. In the 1960s, mouth-to-mouth resuscitation was resumed. At present, five rescue breaths should be carried out at the beginning of resuscitation procedures for a person taken out of the water. The effectiveness of indirect heart massage in restoring heart rate in drowning people was also confirmed. In the first breathing apparatus only the exhaled air of the rescuer was used. Currently, breathing apparatus with oxygen from an oxygen cylinder is used. Changes in the field of water rescue in Poland, concerning CPR and first aid were carried out simultaneously with changes occurring in the world.

International organizations associated in ILCOR have created a universal algorithm for basic resuscitation procedures, which in Poland are used by paramedics, units (including WOPR) cooperating with the State Emergency Medical Services (PRM) and people trained in the first aid. The use of new devices to conduct artificial respiration and the introduction of a mandatory KPP course for water rescuers has improved the quality of resuscitation procedures. Currently, the rescuer working alone in the swimming pool is able to conduct CPR from the first minutes of cardiac arrest until the arrival of the ambulance. Taking into account the fact that professional lifesavers carry out a small number of resuscitations in a year, one should consider introducing more frequent first aid training. This refresher course should take place before the summer season. Additional research in this area is necessary. It would allow determining the optimal frequency with which mandatory refresher training for water rescuers could be introduced. Due to the epidemiological situation in Poland and in the world, there is a need for continuous selfimprovement of their skills and acquiring the latest knowledge by water rescuers. 


\section{References}

Acierno, L.J., Worrell, L.T., Safar, P.J. (2007). Father of Modern Cardiopulmonary Resuscitation, Clinical Cardiology, 30, 52-54.

Act amending certain acts in the field of the health care system related to preventing, counteracting and combating COVID-19 (2020). Journal of Laws of the Republic of Poland, 567.

Baskett, P.J., Peter, J., Safar, P.J. (2001). The early years 1924-1961, the birth of CPR. Resuscitation, 50, 17-22.

Beck, C.S, Pritchard, W.H, Feil, H.S (1947). Ventricular fibrillation of long duration abolished by electric shock. Journal of the American Medical Association, 135, 985.

Cooper, J.A, Cooper, J.D, Cooper, J.M. (2006). Cardiopulmonary Resuscitation: History, Current Practice, and Future Direction. Circulation, 114, 2839-2849.

Decision no. 17/2009 of the President of the Water Volunteer Ambulance Service of December 10, 2009 on the course programs (2009).

Decision no. 21/10 of the President of the Water Volunteer Ambulance Service of December 29, 2010 on the programs of preparation courses for the grades for lifesavers and instructors (2010).

Kołodziej, R., Tabaczek-Bejster, I., Dudziak, A. (2014). Ratownictwo wodne-wybrane zagadnienia, Rzeszów: Uniwersytet Rzeszowski.

Kucmin, T., Płowaś-Goral, M., Nogalski, A. (2015). Krótka historia resuscytacji - wpływ doświadczeń z przeszłości na obecnie stosowane techniki i metody [A brief history of resuscitation - the impact of past experience on currently used techniques and methods]. Polski Merkuriusz Lekarski, XXXVIII (224), 123-126.

Malinowska-Zaprzałka, M. (1998). Podstawy Pierwszej Pomocy w Ratownictwie Wodnym [Basics of First Aid in Water Rescue]. Białystok.

Olasveengen, T., Castrén, M., Handley, A., Kuzovlev, A., Monsieurs, K.G., Perkins, G., Ra!ay, V., Ristagno, G., Semeraro, F., Smyth, M., Soar, J., Svavarsdóttir, H. (2020). Basic Life Support. In: European Resuscitation Council COVID-19 Guidelines. European Resuscitation Council, 6-8.

Peden, M.M., McGee, K. (2004) The epidemiology of drowning world-wide. Injury Control and Safety Promotion, 10 (4),195-199.

Przylipiak, M., Witkowski, M. (1977). Nurkowanie w niezależnych aparatach powietrznych i ratowanie tonących [Diving in independent air aparatus and saving drowning]. Warszawa: Ministerstwo Obrony Narodowej.

Regulation of the Council of Ministers on determining the safety conditions of persons staying in the mountains, swimming, bathers and practicing water sports (1997). Journal Laws of the Republic of Poland, 358.

Regulation of the Minister of Health amending the regulation on the course in qualified first aid (2019). Journal of Laws of the Republic of Poland, 2408.

Regulation of the Minister of the Home Affairs on the requirements for the provision of designated water areas with rescue and auxiliary equipment, signaling and warning devices as well as medical equipment, medicines and sanitary ware (2012). Journal Laws of the Republic of Poland, 261.

Resolution No. 1/11/99 of the Presidium of the Main Board of WVRS of December 10, 1999 on the WOPR lifesavers and instructors degrees (1999).

Safar, P.J, Escarraga, L.A., Chang, F. (1954). Upper airway obstruction in the unconscious patient. Journal of Applied Physiology, 14 (5), 760-764.

Safar, P.J., Kochanek, P.M. (2002) Therapeutic hypothermia after cardiac arrest. The New England Journal of Medicine, 346 (8), 612-613.

Safar, P.J. (1989) History of cardiopulmonary-cerebral resuscitation. In: W. Kaye, N. Bircher (eds.), Cardiopulmonary Resuscitation (pp. 1-53). New York: Churchill Livingstone.

Skalski, J. (2003a) Dawne dzieje resuscytacji i reanimacji [The old history of resuscitation and reanimation]. Szlachetne Zdrowie, Kwartalnik Śląskiego Centrum Chorób Serca, 3, 2.

Skalski, J. (2003b) Dzieje reanimacji i resuscytacji [History of resuscitation and reanimation], Anestezjologia Intensywna Terapia, 3 , 194-198.

Soar, J, Deakin, C.D., Nolan, J.P., Abbas, G., Alfonzo, A., Handley, A.J., Lockey, D., Perkins, G.D., Thies, K. (2005). European Resuscitation Council Guidelines for Resuscitation. Cardiac arrest in special circumstances. Resuscitation, 67, 135-170.

Sprawozdanie z działalności władz PZP w roku jubileuszowym 1947 (1947) [Report on the activities of the PZP authorities in the jubilee year of 1947]. Poznań. 
Śniadecki, J. (1840) O przypadkach pozornej śmierci i sposobach przywracania tak obumarłych do życia. Dzieła Jędrzeja Śniadeckiego. T. 2. Warszawa.

Tabaczek-Bejster, I. (2012). Działalność Wodnego Ochotniczego Pogotowia Ratunkowego (1962-1989). Warszawa: ZG WOPR.

Tabaczek-Bejster, I., Kiszka, J., Ozga, D. (2018). Is the Water Rescue Service in Poland Heading in the Right Direction? Preparing Lifeguards to the Standards of First Aid in Europe. Wilderness Environ Med., 29 (2), 279-280.

Tabaczek-Bejster, I., Konieczny, G. (2020). Działalność Wodnego Ochotniczego Pogotowia Ratunkowego (1989-2012). Rzeszów: Uniwersytet Rzeszowski.

Taw, R.L. (1991). Dr F. Maass: 100th anniversary of „new” CPR. Clinical Cardiology, 14 (12), 1000-1002.

Training instruction No. 1/75 on the principles of conducting training courses in the field of water rescue of various levels (1975). Warszawa: ZG WOPR.

Truhlár̆, A., Deakin, C.D., Alfonzo, A., Bierens, J.L., Brattebo, G. (2015). European Resuscitation Council Guidelines for Resuscitation 2015, Section 4. Cardiac arrest in special circumstances. Resuscitation, (95), 148-201.

V National Congress of WVRS Delegates (1987). Report on activities for the years 1982-1986. Warszawa.

Watson, R.S., Cummings, P., Quan, L., Bratton, S., Weiss, N.S. (2001). Cervical spine injuries among submersion victims. J. Trauma, $51,658-662$.

Wernic, L. (1994) Jak ratować tonących? [How to save drowning?] Zarząd Główny WOPR w Warszawie. Kielce: Agencja WydawniczoReklamowa „EMES”.

Witkowski, M. (1975). Ratownictwo wodne jako jedna z dziedzin działalności Polskiego Związku Pływackiego [Water lifesaving as one of the areas of activity of the Polish Swimming Association]. Konferencja naukowo-metodyczna z okazji 50-lecia Polskiego Związu Pływackiego. Warszawa: PZP.

Żagle i Jachting Motorowy (1985), 6, 13.

Cite this article aS: Tabaczek-Bejster, I., Kiszka, J., Konieczny, G. (2021). Changes Related to the First Aid in Water Lifesaving in Poland (1962-2020). Central European Journal of Sport Sciences and Medicine, 4 (36), 45-55. DOI: 10.18276/cej.2021.4-05. 